\title{
Cell Cycle Regulators in the Neuronal Death Pathway of Amyotrophic Lateral Sclerosis Caused by Mutant Superoxide Dismutase 1
}

\author{
Minh Dang Nguyen, ${ }^{1}$ Mathieu Boudreau, ${ }^{2}$ Jasna Kriz, ${ }^{1}$ Sébastien Couillard-Després, ${ }^{1}$ David R. Kaplan, ${ }^{3}$ and \\ Jean-Pierre Julien ${ }^{1}$ \\ ${ }^{1}$ Research Institute of the McGill University Health Center, Centre for Research in Neuroscience, Montreal, Quebec, Canada H3G 1A4, ${ }^{2}$ Brain Tumor \\ Research Centre, Montreal Neurological Institute, McGill University, Montreal, Quebec, Canada H3A 2B4, and ${ }^{3}$ The Hospital for Sick Children, Toronto, \\ Ontario, Canada M5G 1X8
}

There is growing evidence for involvement of members of the cyclin-dependent kinase (Cdk) family in neurodegenerative disorders and in apoptotic death of neurons subjected to various insults. After our recent report that a deregulation of Cdk5 activity by p25 may contribute to pathogenesis of amyotrophic lateral sclerosis (ALS), we further examined the possible involvement of other Cdks in mice expressing a mutant form of superoxide dismutase ( $\mathrm{SOD} 1{ }^{\mathrm{G} 37 \mathrm{R}}$ ) linked to ALS. No substantial changes in Cdk2 or Cdk6 distribution and kinase activities were detected in spinal motor neurons from SOD $1{ }^{\mathrm{G} 37 \mathrm{R}}$ mice when compared with normal mice. Of particular interest was the upregulation and mislocalization of $\mathrm{Cdk} 4$, a regulator of the $\mathrm{G}_{1}-\mathrm{S}$ checkpoint of the cell cycle, in motor neurons of SOD1 ${ }^{\mathrm{G} 37 \mathrm{R}}$ mice. The increase of Cdk4 activity in SOD1 ${ }^{\mathrm{G} 37 \mathrm{R}}$ mice was associated with an increase in nuclear Cdk4, cyclin D1, its coactivator, and with the abnormal phosphorylation of the retinoblastoma $(\mathrm{Rb})$ protein at Cdk phosphorylation sites. Pharmacological treatment of SOD1 ${ }^{\mathrm{G} 37 \mathrm{R}}$ mice with minocycline, a compound that attenuates microgliosis and slows down disease, lessened the dysregulation of Cdk5/Cdk4 and the phosphorylation of $\mathrm{Rb}$. Interestingly, phospho- $\mathrm{Rb}$ was immunoprecipitated with anti-Cdk4 but not with anti-Cdk5 antibodies, suggesting a key role for Cdk4 in the phosphorylation of $\mathrm{Rb}$. Remarkably, the overexpression of a transgene coding for human neurofilament $\mathrm{H}$, a phosphorylation sink for deregulated Cdk5 activity by p25, resulted in a reduction in levels of nuclear Cdk 4 and $\mathrm{Rb}$ phosphorylation. These results indicate that a cell cycle signaling at the neuronal $\mathrm{G}_{1}-\mathrm{S}$ checkpoint subsequent to $\mathrm{Cdk} 5$ deregulation may constitute a critical step of the neuronal death pathway in ALS caused by mutant SOD1.

Key words: amyotrophic lateral sclerosis; $\mathrm{Cu} / \mathrm{Zn}$ superoxide dismutase; cyclin-dependent-kinase; retinoblastoma; cell cycle; inflammation; neuronal apoptosis; transgenic mice

\section{Introduction}

Cyclin-dependent kinases (Cdks) are proline-directed Ser-Thr kinases phosphorylating cell cycle and cytoskeletal proteins (Morgan, 1997; Tannoch et al., 2000). Classical Cdks such as Cdk2, Cdk4, and Cdk6 associate with cyclin regulatory subunits to control cell cycle events and differentiation processes (Morgan, 1997; Tannoch et al., 2000). In contrast to these mitotic Cdks, activation of Cdk5 does not require the association with a cyclin but the critical binding to its neuron-specific regulatory

\footnotetext{
Received April 30, 2002; revised Dec. 4, 2002; accepted Dec. 19, 2002.

This work was supported by the Canadian Institutes of Health Research (CIHR) and the Center for ALS Research at Johns Hopkins University (Baltimore, MD). M.D.N. was a recipient of a K. M. Hunter/CIHR scholarship and holds a postdoctoral long-term fellowship from the Human Frontier Science Program Organization. M.B. was a recipient of a Fonds de la Recherche en Santé du Quèbec/Fonds Concertés d'Action à la Recherche scholarship. J.-P.J. received a CIHR senior investigator award. The technical help of P. Hince, D. Houle, and Geneviève Gowing is gratefully acknowledged. We are grateful to Dr. P. Branton (McGill University) for the glutathione S-transferase-Rb plasmid, Dr. D. L. Price (John Hopkins University) and Dr. D. W. Cleveland (University of California, San Diego, CA) for the kind gift of SOD1 ${ }^{\text {G37R }}$ mice (line 29), and Dr. L.-H. Tsai for hosting part of this study at the Harvard Medical School.

Correspondence should be addressed to Dr. Jean-Pierre Julien, Research Institute of the McGill University Health Center, 1650 Cedar Avenue, Montreal, Quebec, Canada H3G 1A4. E-mail: Jean-Pierre.Julien@mcgill.ca.

M. D. Nguyen's present address: Department of Pathology, Harvard Medical School, Howard Hughes Medical Institute, Boston MA 02115

S. Couillard-Després's present address: Department of Neurology, Volkswagen Foundation Junior Group, University of Regensburg, Universitatsstrasse 31, 93053 Regensburg, Germany.

Copyright $\odot 2003$ Society for Neuroscience $\quad 0270-6474 / 03 / 232131-10 \$ 15.00 / 0$
}

subunit $\mathrm{p} 35$. The $\mathrm{p} 35 / \mathrm{Cdk} 5$ complex is essential for neurite outgrowth, cell adhesion, cortical development, neuronal adaptive changes, and motor functions (Dhavan and Tsai, 2001; Smith et al., 2001).

Previous reports demonstrated that induction and activation of Cdk2, Cdk4, and Cdk6 in neurons by stress drive them into the cell cycle and ensuing apoptosis, a phenomenon that can be rescued by inhibitors or dominant negative forms of the kinases (Park et al. 1997a,b, 1998a,b, 2000; Copani et al., 1999; Stefanis et al., 1999; Osuga et al., 2000; Ino and Chiba, 2001; Katchanov et al., 2001). The abnormal upregulation of mitotic proteins in neurons has been observed during neurodegenerative disorders, including Alzheimer's disease and amyotrophic lateral sclerosis (ALS), the most common form of human motor neuron disease (Arendt et al., 1996; McShea et al., 1997; Vincent et al., 1996, 1997; Busser et al., 1998; Husseman et al., 2000; Ranganathan et al., 2001; Yang et al., 2001) (for review on ALS, see Cleveland and Rothstein, 2001; Julien, 2001). Furthermore, mislocalization and deregulation of Cdk5 activity by association with $\mathrm{p} 25$, a toxic calpain-truncated form of $\mathrm{p} 35$, also participate in the pathogenesis of Alzheimer's disease and ALS (Patrick et al., 1999; Lee et al., 2000; Nguyen et al., 2001a). These data provided compelling evidence that alterations in the activities of Cdks can be noxious to neurons (for review, see Nguyen et al., 2002b). 
Missense mutations in the gene coding for $\mathrm{Cu} / \mathrm{Zn}$ superoxide dismutase 1 (SOD1), located on chromosome 21, account for $\sim 3 \%$ of all ALS cases (Rosen et al., 1993; Cudkowicz et al., 1997). The SOD1 protein is a cytosolic free radical scavenging metalloenzyme protecting cells from oxidative stress (Fridovich, 1986). Transgenic mice expressing mutant SOD1 develop motor neuron disease resembling ALS, through a gain of unidentified deleterious properties (Gurney et al., 1994; Wong et al., 1995; Tu et al., 1996; Bruijn et al., 1997, 1998; Morrison et al., 1998). Several mechanisms have been proposed to account for such toxicity, including oxidation- and nitration-related damages, protein aggregation, excitotoxicity, inflammation, mitochondrial damage, disturbance of calcium homeostasis, and aberrant phosphorylation by deregulated Cdk5. The outcome of mutant SOD1 toxicity culminates in apoptosis featured by an unbalance in levels of Bcl-2 family members (Martin, 1999; Vukosavic et al., 1999; Gonzalez de Aguilar et al., 2000) and caspase activation (Pasinelli et al., 1998, 2000; Li et al., 2000; Vukosavic et al., 2000). Here we report the detection of abnormal cell cycle signaling associated with $\mathrm{Cdk} 5$ deregulation in mice expressing a mutant SOD1 $\left(\mathrm{SOD} 1^{\mathrm{G} 37 \mathrm{R}}\right.$ ) linked to human ALS and its potential involvement in motor neuron death.

\section{Materials and Methods}

Generation of SOD1 $1^{\text {G37R }}$; $h N F-H$ mice and minocycline treatment protocol. The inbred C57BL6 SOD1 G37R mice (line 29) used in this study have a life span of 11-12 months (Nguyen et al., 2000, 2001a). SOD1 ${ }^{\text {G37R }}$ mice (line 29) overexpressing human neurofilament $\mathrm{H}$ (NF-H) were generated according to the methods of Nguyen et al. (2001a) and exhibit a life span of 13-18 months (Couillard-Després et al., 1998, Nguyen et al., 2001a). Treatment of SOD1 ${ }^{\text {G37R }}$ mice (line 29) with minocycline was performed according to the methods of Kriz et al. (2002). The SOD1 ${ }^{\mathrm{G} 37 \mathrm{R}}$ mice were housed at room temperature $\left(21^{\circ} \mathrm{C}\right)$ and in a light-controlled environment with ad libitum access to the food and water. The study was performed using groups of transgenic littermates derived from the breeding of heterozygous SOD1 ${ }^{\mathrm{G} 37 \mathrm{R}}$ mice. The mouse littermates were fed a regular rodent food (Teklad; Harlan, Indianapolis, IN) and were randomly divided into minocycline-treated and control groups, including wild-type littermates. To avoid any potential interference with the minocycline antibacterial effects, mice were kept in a pathogen-free facility. At the age of 9 months, SOD1 ${ }^{\mathrm{G} 37 \mathrm{R}}$ mice from the experimental groups were administered minocycline in the diet. Minocycline (Sigma, Oakville, Ontario, Canada) was delivered in the special custom-made rodent diet (Teklad; Harlan) at a concentration of $1 \mathrm{gm} / \mathrm{kg}$. For the control groups, the regular diet was continued until the mice reached end-stage disease. To confirm the protective effects of minocycline, two independent experiments were performed at 6 month intervals with different sets of transgenic SOD $1{ }^{\mathrm{G} 37 \mathrm{R}}$ mice. Similar results were obtained in both cases. All the mouse genotypes were determined by Southern blotting of tail DNA. The use of animals and all surgical procedures described in this article were performed according to The Guide to the Care and Use of Experimental Animals of the Canadian Council on Animal Care (www.ccac.ca).

Immunohistochemistry and immunofluorescence analysis. Mice were given a lethal overdose of chloral hydrate and perfused with $0.9 \% \mathrm{NaCl}$ and then with fixative (3\% v/v glutaraldehyde in PBS buffer, $\mathrm{pH} 7.4$ ). Tissue samples were immersed in fixative. Fifty micrometer tissue sections from glutaraldehyde-perfused mice were prepared using a vibratome. Floating sections were rinsed in PBS and treated for $30 \mathrm{~min}$ with a $1 \%(\mathrm{w} / \mathrm{v})$ sodium borohydride solution to reduce epitope masking by glutaraldehyde. The sections were then blocked for $1 \mathrm{hr}$ in a PBS solution containing $3 \%(\mathrm{w} / \mathrm{v})$ BSA, $0.5 \%(\mathrm{v} / \mathrm{v})$ Triton X-100, and $0.03 \%(\mathrm{w} / \mathrm{v})$ hydrogen peroxide and incubated overnight at room temperature with agitation in a PBS solution containing 3\% (w/v) BSA and $0.05 \%(\mathrm{w} / \mathrm{v})$ Triton X-100 with primary antibodies against Cdk2 (H-298), Cdk4 (C22), Cdk5 (C-8), Cdk6 (H-230), PSTAIRE, the conserved motif of the cdc2 kinase family (all from Santa Cruz Biotechnology, Santa Cruz, CA), cyclin D1, D2, and D3 (Novo Castra), retinoblastoma (Rb; phospho-Ser795 and phospho-Ser-807/Thr-811), and activated caspase-3 (ASP 175) (both from Cell Signaling Technology). All the antibodies were diluted at 1:500. Immunohistochemical staining was developed using a Vector ABC kit (Vector Laboratories, Burlington, Ontario, Canada) and Sigmafast tablets (Sigma). For immunofluorescence experiments, mice were perfused with $0.9 \% \mathrm{NaCl}$ and then with fixative $(4 \% \mathrm{v} / \mathrm{v}$ paraformaldehyde in PBS buffer, $\mathrm{pH}$ 7.4). Tissue samples were processed according to the methods of Nguyen et al. (2001a). Tissues samples were incubated with antibodies against MAP2 (1:500; Roche Molecular Biochemicals, Indianapolis, IN), Cdk4, and Cdk2 (1:500; Santa Cruz Biotechnology). Nuclei were stained with DAPI.

Immunoprecipitation and kinase assays. The mouse spinal cords were homogenized in lysis buffer (20 mu Tris, pH 8.0, $137 \mathrm{~mm} \mathrm{NaCl}, 10 \%$ glycerol, $1 \% \mathrm{NP}-40,1 \mu \mathrm{g} / \mathrm{ml}$ leupeptin, $10 \mu \mathrm{g} / \mathrm{ml}$ apoprotinin, $0.5 \mathrm{~mm}$ sodium orthovanadate, and $1 \mathrm{~mm}$ PMSF). A histone $\mathrm{H} 1$ kinase assay was performed as follows. Spinal cord lysates (500 or $1000 \mu \mathrm{g}$ ) were immunoprecipitated with antibodies against Cdk2, Cdk4, Cdk5, or Cdk6. Antibodies $(0.5-3 \mu \mathrm{g})$ were added, and samples were incubated and mixed at $4^{\circ} \mathrm{C}$ for $3 \mathrm{hr}$. Afterward, protein A-Sepharose was added (50:50 v/v), and the samples were incubated for $1 \mathrm{hr}$ at $4^{\circ} \mathrm{C}$. The samples were spun for $20 \mathrm{sec}$ at 13,000 rpm before washes with lysis buffer (three to five times). The samples were then washed successively three times with lysis buffer and twice with $1 \times$ kinase buffer (without ATP). Histone $\mathrm{H} 1$ or Rb protein (glutathione $\mathrm{S}$-transferase- $\mathrm{Rb}$ ) was added as a substrate in the in vitro kinase assays as described previously by Nguyen et al. (2001a).

Nuclear fractionation. The tissue was washed in cold PBS, cut up in pieces, and resuspended in cold hypotonic buffer $\left(1 \mathrm{mM} \mathrm{NaHCO}_{3}\right.$ and 5 mM $\mathrm{MgCl}_{2}, \mathrm{pH}$ 7.5) with protease inhibitor mixture tablets (Roche Molecular Biochemicals) and sodium orthovanadate. Samples were incubated in hypotonic buffer for $10 \mathrm{~min}$. After incubation, the samples were homogenized using Dounce homogenization (10 strokes). Samples were centrifuged at $3200 \mathrm{rpm}$. Pelleted nuclei were resuspended in hypotonic buffer for $10 \mathrm{~min}$ and centrifuged at 13,000 rpm for $10 \mathrm{~min}$. The nuclear pellet was solubilized in NP-40 lysis buffer, vortexed two times for $30 \mathrm{sec}$, and rocked at $4^{\circ} \mathrm{C}$ for $20 \mathrm{~min}$. The sample was then centrifuged at 13,000 rpm for $15 \mathrm{~min}$, and a supernatant containing soluble nuclear proteins was used for immunocomplex kinase assays and Western blots.

Western blot analysis. The mice were given a lethal intraperitoneal injection of chloral hydrate. Immediately afterward, total protein extracts of the spinal cord were obtained by homogenization in SDS-urea $\beta$-mercaptoethanol ( $0.5 \%$ SDS and $8 \mathrm{M}$ urea in $\mathrm{pH} 7.4$ phosphate buffer) or NP-40 lysis buffer with a mixture of protease inhibitors (PMSF, leupeptin, pepstatin, and apoprotinin). The supernatant was collected after centrifugation at $10,000 \times g$ for 20 or $30 \mathrm{~min}$. The protein concentration was estimated by the Bradford procedure (Bio-Rad, Hercules, CA). Proteins $(20$ or $50 \mu \mathrm{g})$ were fractionated on $7.5 \%$ SDS-PAGE and blotted on a nitrocellulose or polyvinylidene difluoride membrane for Western blot analysis. Membranes were incubated with antibodies against Cdk2, Cdk4, Cdk5, Cdk6, cyclin D1, D2, and D3, phospho-Rb (Ser-795 and Ser-807/Thr-811; dilutions of 1:500). The Western blots were revealed by Renaissance, a Western blot chemiluminescence kit from PerkinElmer Life Sciences (Boston, MA).

\section{Results \\ Abnormal expression of cell cycle regulators in SOD1 ${ }^{\text {G37R }}$ mice}

Immunohistochemistry of spinal cord sections was performed to investigate the subcellular distribution of mitotic Cdks (Cdk4, Cdk6, and Cdk2) and of their target Rb in normal and SOD1 G37R mice at 11-12 months of age (end stage of disease). Antibodies against Cdk5, Cdk4, Cdk6, and Cdk2 yielded diffuse immunoreactivities in spinal motor neurons of normal mice (Fig. $1 A, C, E, G)$. An antibody recognizing the PSTAIRE motif common to Cdk1, Cdk2, and Cdk3 also produced very weak immu- 



Figure 1. Immunohistochemical staining for Cdks and phospho-pRb in the spinal cord of normal and SOD1 ${ }^{\text {G37R }}$ mice. Antibodies against Cdk5, Cdk4, Cdk6, and Cdk2 yielded diffuse immunostaining in spinal cord sections of normal mice $(A, C, E, G)$. In contrast, strong immunostaining was obtained for Cdk5 and Cdk4 especially in nuclei of motor neurons from SOD1 ${ }^{637 R}$ mice $(B, D$, white arrows). A high-magnification micrograph at the left corner of $D$ shows a Cdk4-positive nucleus in a motor neuron. Cdk6 immunostaining was enhanced in subsets of motor neurons from SOD1 ${ }^{\text {G37R }}$ mice (F, white arrows), whereas (dk2 immunoreactivities were detected in cell bodies of motor neurons (H, white arrows) and in glial cells (H, white arrowheads) of SOD1 ${ }^{\text {G37R }}$ mice. PSTAIRE antibodies recognizing $\mathrm{Cdk1}$-Cdk3 stained only glial cells in the spinal cord of $S 0 D 1^{\mathrm{G37R}}$ mice (J, white arrowheads) but not normal mice (I). Phosphorylated Rb was detected in the nucleus of spinal motor neurons in normal and SOD ${ }^{\mathrm{G} 37 \mathrm{R}}$ mice with phospho-Ser-795-Rb antibodies $(K, L)$. However, the antibodies against phospho-Ser-795-Rb and phospho-Ser-807/Thr-811-Rb detected phosphorylated pRb in cytoplasm of spinal motor neurons exclusively in SOD1 ${ }^{\text {G37R }}$ mice $(L-N$, white arrows). Note that two to five neurons per slice from end-stage glutaraldehyde-perfused SOD1 mice exhibit staining for nuclear Cdk4 or phospho-Ser-807/Thr-811-Rb. Western blot analysis revealed 110 kDa phospho-Ser-807/Thr-811-Rb immunoreactivities only in samples from S0D1 ${ }^{\text {G37R }}$ mice but not in normal mice (0). In contrast, phospho-Ser-795 antibodies recognized $110 \mathrm{kDa}$ phospho species of Rb in both SOD1 ${ }^{637 R}$ and normal samples $(0)$. These immunoreactivities compatible with the immunostaining experiments can be abolished with alkaline phosphatase treatment, indicating specificity for both phospho-Rb antibodies. The spinal cord sections were obtained from four SOD1 ${ }^{\text {G37R }}$ mice (line 29) at the end stage of disease (11-12 months of age) and four normal littermates. Scale bar, $30 \mu \mathrm{m}$. The spinal cord lysates were obtained from five SOD1 ${ }^{\text {G37R }}$ mice (line 29 ) at the end stage of disease (11-12 months of age) and three normal littermates. All experiments were repeated more than two times.

noreactivity in the spinal cord of normal mice, reflecting the lack of cell cycle molecules in normal postmitotic neurons as well as a paucity of proliferating glial cells.

In contrast, the spinal motor neurons of SOD $1^{\mathrm{G} 37 \mathrm{R}}$ mice exhibit elevated immunoreactivities for Cdk5 and Cdk4 (Fig. $1 B, D)$. The Cdk4 staining was found in numerous motor neurons and selectively in their nucleus (Fig. $1 D$, white arrows, left corner). Cdk6 immunoreactivity was also detected in a lower proportion of motor neurons (Fig. 1E, white arrows). Because Cdk6 activation occurs downstream of Cdk4 activation in the cell cycle pathway, the scarcity of Cdk6-positive motor neurons may reflect the end of mitotic activation in these cells. In support of this view is the finding that the subcellular localization of $\mathrm{Cdk} 2$, which is activated after Cdk6 in mitosis, remains unchanged in the cytoplasm of motor neurons in SOD ${ }^{\mathrm{G} 37 \mathrm{R}}$ mice (Fig. $1 \mathrm{H}$, white arrows). The unaltered Cdk2 distribution suggests that motor neu- rons do not cross the late $G_{1}-S$ phase in their attempted reentry into the cell cycle. Nonetheless, there was induction of Cdk2 in glial cells from the spinal cord of SOD $1{ }^{\mathrm{G} 37 \mathrm{R}}$ mice (Fig. $1 \mathrm{H}$, white arrowheads), which is compatible with the gliosis and inflammation occurring in these mice (Wong et al., 1995; Tu et al., 1996; Bruijn et al., 1997; Morrison et al., 1998; Nguyen et al., 2001b). The involvement of Cdk1, Cdk2, and Cdk3 in proliferation of glial cells is further supported by the PSTAIRE immunoreactivities detected in glial cells of the spinal cord from SOD ${ }^{\mathrm{G} 37 \mathrm{R}}$ mice (Fig. $1 \mathrm{~J}$, white arrowheads).

Double-immunofluorescence experiments confirmed the cytosolic distribution of Cdk2 in spinal motor neurons of both normal and SOD $1^{\text {G37R }}$ mice (Fig. $2 A-F$ ), whereas Cdk4 was relocated from the cytosol to the nucleus of spinal motor neurons of SOD $1^{\mathrm{G} 37 \mathrm{R}}$ mice when compared with normal mice (Fig. $2 \mathrm{G}-$ $L)$. The RT-97 antibody was used to stain phosphorylated NF-H 
in axons and dendrites of both normal and SOD $1^{\text {G37R }}$ mice, thereby delimiting the neuronal cell bodies. Double immunofluorescence with anti-MAP2 or antiCdk4 antibodies with DAPI staining confirmed the presence of $\mathrm{Cdk} 4$ in the nucleus of spinal motor neurons from SOD $1^{\text {G37R }}$ mice (Fig. $2 \mathrm{M}-\mathrm{O}$ ). The MAP2 antibody used (clone AP-20) recognizes the high-molecular weight MAP2a and $2 \mathrm{~b}$ $(280 \mathrm{kDa})$ and reacts with dendrites and cell bodies of neurons. MAP2a and $2 b$ are essential for the maintenance and survival of neurons; the unhealthy appearance of the Cdk4/MAP2-positive neurons indicates abnormalities of MAP2a and $2 b$ in degenerating motor neurons having Cdk4 upregulation. Evidence for such alteration was provided by our findings of decreases of MAP $2 a$ and $2 b$ in in spinal cord extracts from SOD $1^{\text {G37R }}$ mice (Abi-Farah et al., 2002). Our results are also in agreement with a recent study reporting a decrease of MAP2a and 2b in motor neurons of ALS patients (Kikuchi et al., 1999). Therefore, the combined results indicate that motor neurons with cytoskeletal abnormalities at a late stage of disease reentered the early $\mathrm{G}_{1}-\mathrm{S}$ phase of cell cycle with $\mathrm{Cdk} 4$ and Cdk6 involvement but not with Cdk2 involvement.

Interestingly, the dysregulation of Cdk5 and Cdk4 was not detected at early stages of disease in 3- and 6-month-old SOD $1^{\text {G37R }}$ mice (Fig. $3 A-C, E-G$ ), a time when defects in axonal transport and mitochondrial vacuolization have been reported (Wong et al., 1995; Williamson and Cleveland, 1999) (for review, see Cleveland and Rothstein, 2001; Julien, 2001). The first signs of dysregulation of Cdk5 and Cdk4 appear at 8-9 months, a time when neurodegeneration occurs (Fig. 3D,H) (Nguyen et al., 2001a).

As cyclin D1, D2, and D3 are usually associated with Cdk4 and Cdk6 activation, we examined the expression of these cyclins in the spinal cord of normal and SOD $1^{\text {G37R }}$ mice at the end stage of disease

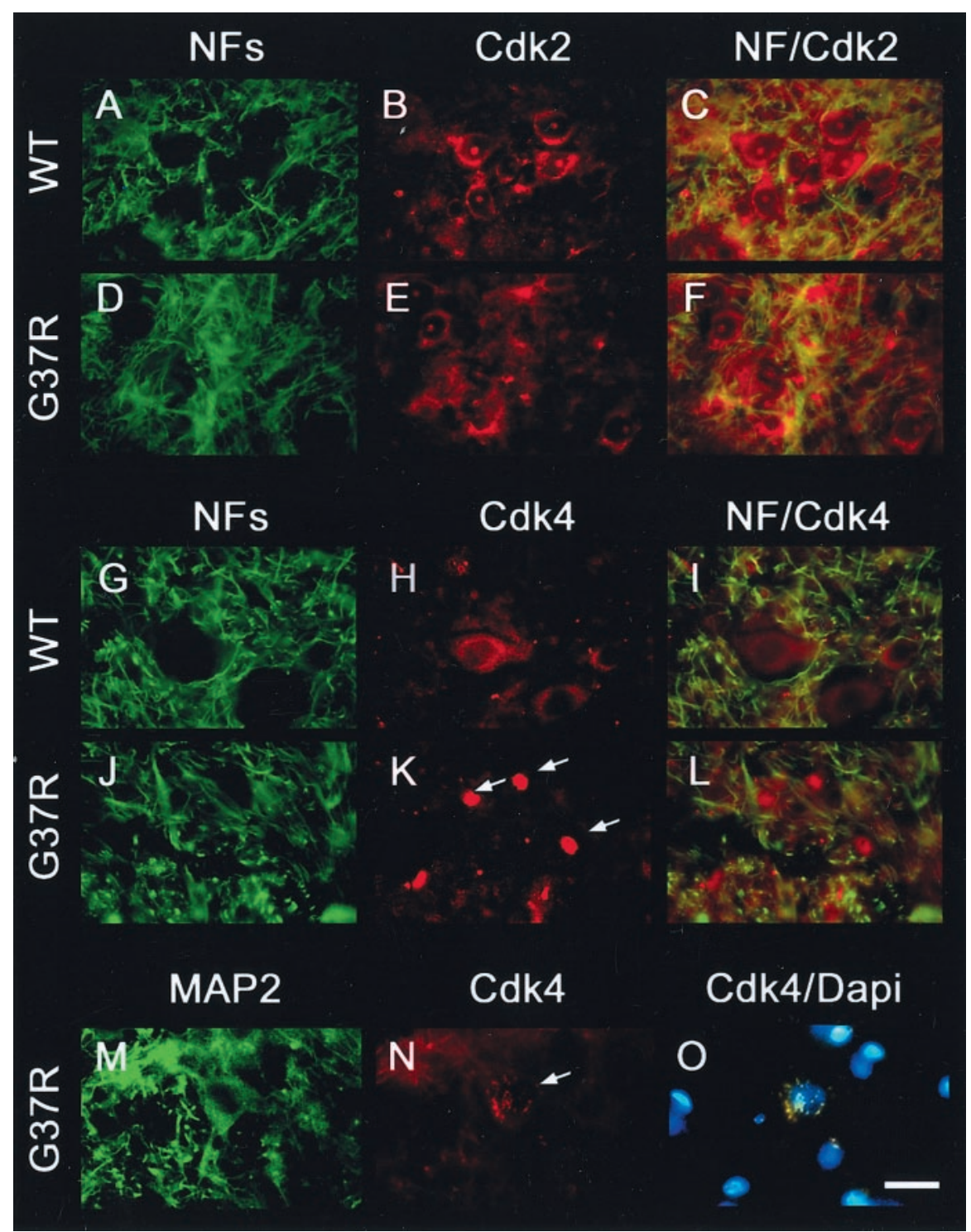

Figure 2. Mislocalization of $\mathrm{Cdk} 4$ but not $\mathrm{Cdk} 2$ in spinal motor neurons of $\mathrm{SOD} 1{ }^{\mathrm{G37R}}$ mice. Double-immunofluorescence staining confirmed the mislocalization of Cdk4 but not $C d k 2$ in the nucleus of spinal motor neurons in SOD1 $1{ }^{\mathrm{G} 37 \mathrm{R}}$ mice. Cdk2 was detected in the cytoplasm and nucleolus of spinal motor neurons in normal $(W T ; A-C)$ and SOD $1{ }^{\mathrm{G} 37 \mathrm{R}}(D-F)$ mice, whereas $C \mathrm{dk} 4$ was found in neuronal cell bodies from normal mice $(G-I)$ and neuronal nuclei from SOD $1{ }^{\text {G37R }}$ mice $(J-L)$. RT-97 antibodies were used to stain dendritic and axonal phospho-NF-H, thereby delimiting the neuronal cell bodies. The nuclear localization of $\mathrm{Cdk} 4$ in spinal motor neurons of $S O D 1^{G 37 R}$ mice was confirmed by double immunostaining with Cdk4 and MAP2 antibodies and DAPI staining $(M-0)$. A secondary FITC-labeled antibody and a secondary rhodamine-labeled antibody were used to detect phospho-NF-H or MAP-2 and Cdk2 or Cdk4, respectively. Experiments were performed with spinal cord sections or spinal cord lysates from five SOD $1{ }^{\mathrm{G} 7 \mathrm{R}}$ mice (line 29) at the end stage of disease (11-12 months old) and four normal littermates. Scale bar, $20 \mu \mathrm{m}$. All experiments were repeated more than two times.
(Fig. 4). Immunohistochemical staining

showed higher levels of cyclin D1 in the nucleus of motor neurons in the ventral horn of spinal cord of SOD $1^{\mathrm{G} 37 \mathrm{R}}$ mice when compared with normal mice (Fig. $4 B$ ). To clearly demonstrate that nuclei of SOD1 ${ }^{\mathrm{G} 37 \mathrm{R}}$ mice are enriched in cyclin D1, we performed nuclear fractionation of spinal cord tissues from both normal mice and mutant SOD1 mice (Fig. $4 H$ ). Cyclin D1 was found to be more abundant in nuclear samples from SOD $1^{\mathrm{G} 37 \mathrm{R}}$ mice. In contrast to cyclin D1, cyclin D2 and D3 are detected mainly in the cytoplasm of the spinal motor neuron cord from both normal and SOD $1^{\text {G37R }}$ mice, as revealed by both immunohistochemistry and nuclear fractionation (Fig. 4C-F,H). The axonal counts at the level of the L5 ventral root for wild-type (WT) and end-stage SOD $1{ }^{\text {G37R }}$ mice are $1052 \pm 97(n=4)$ and $364 \pm$ $34(n=4)$, respectively (Fig. $4 G)$.

\section{Phosphorylation of $\mathrm{Rb}$ at Ser-807 and Ser-811 in motor neurons of SOD1 ${ }^{\text {G37R }}$ mice}

Recent studies showed that phosphorylation of Rb by Cdk 4 and Cdk6 leads to the disruption of the transcription-repressive E2F$1 / \mathrm{Rb}$ complex, causing the inactivation and degradation of $\mathrm{Rb}$, and consequently promotes E2F-1-dependent transcription of proteins involved in mitosis and differentiation (Dyson, 1998; Lipinski and Jacks, 1999). In neurons, Rb phosphorylation by Cdk4 and Cdk6 causes neuronal apoptosis (Park et al. 1997a,b, 1998a,b, 2000; Copani et al., 1999; Stefanis et al., 1999; Osuga et 


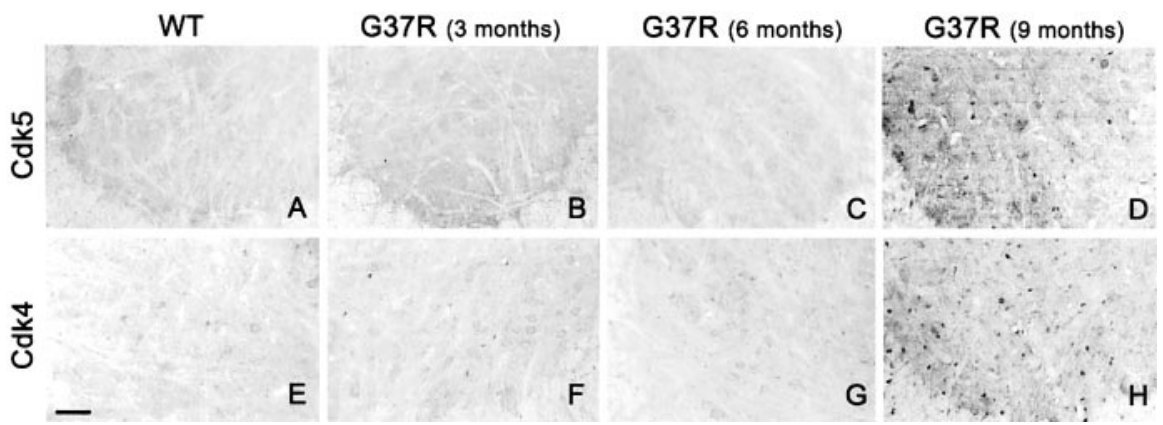

Figure 3. Concomitant dysregulation of $\mathrm{Cdk} 5$ and $\mathrm{Cdk} 4$ in the late stage of disease in $\mathrm{SOD} 1^{\mathrm{G} 37 \mathrm{R}}$ mice. Antibodies against $\mathrm{Cdk} 5$ and $C d k 4$ yielded diffuse immunostaining in spinal cord sections of normal mice $(A, E)$ and 3 - and 6-month-old SOD $1{ }^{\text {G37R }}$ mice $(B$, $F, C, G$, respectively). In contrast, strong immunostaining for $C \mathrm{dk} 5$ and $(\mathrm{dk} 4$, indicative of dysregulation, starts at $8-9$ months of age in $S O D 1^{\mathrm{G} 37 \mathrm{R}}$ mice $(D, H)$. Experiments were performed with spinal cord sections from three $S 0 D 1^{\mathrm{G} 37 \mathrm{R}}$ mice (line 29) at each age and three normal littermates and were repeated more than two times.

al., 2000; Ino and Chiba, 2001; Katchanov et al., 2001) (for review, see Copani et al., 2001; Liu and Greene, 2001). Using antibodies against phospho-Ser-807/Thr-811-Rb or phospho-Ser$795-\mathrm{Rb}$, we examined by immunohistochemistry whether the nuclear localization of Cdk4 and Cdk6 in spinal motor neurons of SOD $1{ }^{\text {G37R }}$ mice resulted in abnormal phosphorylation of Rb. Phosphorylation of $\mathrm{Rb}$ at these sites by Cdks has been shown to disrupt the binding of Rb to E2F-1 (Knudsen and Wang, 1997).

Immunostaining with anti-phospho-Ser-795-Rb antibodies yielded a strong nuclear immunoreactivity in motor neurons of normal and SOD $1{ }^{\text {G37R }}$ mice (Fig. 1 K,L). However, unlike in normal mice, cytoplasmic immunostaining occurred in some motor neurons of SOD $1{ }^{\mathrm{G} 37 \mathrm{R}}$ mice (Fig. $1 \mathrm{~L}$, white arrows). Remarkably, the phospho-Ser 807/Thr-811-Rb antibody yielded a robust immunostaining of neuronal cell bodies in the spinal cord of SOD $1^{\text {G37R }}$ mice, whereas a weak and diffuse immunostaining of motor neurons was observed in normal mice (Fig. $1 M, N$ ). To confirm the specificities of phospho-Rb antibodies, spinal cord extracts from SOD ${ }^{\mathrm{G} 37 \mathrm{R}}$ and normal mice were fractionated by SDS-PAGE followed by immunoblotting with phospho-Ser-795 or phospho-Ser-807/Thr-811-Rb antibodies. No phospho-Ser807/Thr-811-Rb immunoreactivities were detected in samples from normal mice (Fig. 1O). However, in extracts from SOD1 ${ }^{\text {G37R }}$ mice, phospho-Ser-807/Thr-811-Rb antibodies recognized $110 \mathrm{kDa}$ phospho species of $\mathrm{Rb}$, confirming a hyperhosphorylation of $\mathrm{Rb}$ at those residues in these extracts (Fig. 1O). Alkaline phosphatase treatment of the blot completely abolished the phospho-Ser-807/Thr-811-Rb signals for the SOD $1{ }^{\text {G37R }}$ samples, confirming the specificity of the signals (Fig. $1 P$ ). We have also tested by Western blot the specificity of phospho-Ser-795-Rb antibodies. In extracts from both normal and SOD $1^{\mathrm{G} 37 \mathrm{R}}$ mice, this antibody recognizes the typical $110 \mathrm{kDa}$ phospho species of $\mathrm{Rb}$ that can be abolished with phosphatase treatment (Fig. 1O,P). These combined results indicate that $\mathrm{Rb}$ is hyperphosphorylated at Ser-807/Thr-811 in the spinal cord of SOD $1{ }^{\text {G37R }}$ mice but not in wild-type mice.

Kinase activities and protein levels of Cdks in SOD1 ${ }^{\mathrm{G} 37 \mathrm{R}}$ mice To obtain further evidence of involvement of cell cycle regulators in the neuronal death pathway of ALS, we determined the protein levels and kinase activities of Cdk4, Cdk6, and Cdk2 in spinal cord extracts from normal and SOD $1{ }^{\text {G37R }}$ mice in the late stage of disease. The protein extracts, prepared as described previously (Nguyen et al., 2001a), were fractionated by SDS-PAGE followed by immunoblotting using specific antibodies. As shown in Figure
5, the total levels of Cdk5, Cdk6, and Cdk2 were similar in SOD $1^{\text {G37R }}$ and normal mice. In contrast, the total and nuclear levels of Cdk4 increased up to threefold in spinal cord of SOD $1^{\text {G37R }}$ mice when compared with normal mice (see Figs. 5, 7), in agreement with the immunohistochemical staining shown in Figure $1 D$.

We performed kinase assays after immunoprecipitation of each kinase from spinal cord extracts using histone $\mathrm{H} 1$ as a substrate for $\mathrm{Cdk} 5$ and $\mathrm{Cdk} 2$ or $\mathrm{Rb}$ as a substrate for Cdk4 and Cdk6. As we reported previously, an approximately twofold increase in Cdk5 activity was detected in SOD $1^{\text {G37R }}$ mice when compared with normal mice (Fig. 5A) (Nguyen et al., 2001a). A very modest increase in Cdk2 activity was found in the spinal cord of SOD $1{ }^{\text {G37R }}$ mice, which may reflect proliferating glial cells entering the cell cycle asynchronously. A dramatic increase of Rb phosphorylation by nuclear Cdk4 activity was detected in samples from SOD ${ }^{\text {G37R }}$ mice compared with normal mice (Fig. 5A). This upregulation of twofold to threefold in Cdk4 kinase activity correlated with an increase of Cdk4 protein levels in the nuclear (Fig. 5) and total fraction (see Fig. 7), as determined by Western blot and by immunohistochemistry (Fig. 1D). No changes in Cdk6 protein levels and kinase activity were detected in spinal cord extracts of SOD1 ${ }^{\text {G37R }}$ mice. This is compatible with the small number of Cdk6-positive motor neurons detected by immunohistochemistry in SOD $1{ }^{\text {G37R }}$ mice (Fig. $1 F$ ).

Because Rb is also a substrate for Cdk5 (Lee et al., 1997), we performed immunoprecipitation assays to determine whether Cdk5 or Cdk4 phosphorylates Rb. Phospho-Rb can only be immunoprecipitated in SOD $1^{\text {G37R }}$ mice with anti-Cdk4 but not anti-Cdk5 antibodies (Fig. 5B). Taken together, these results indicate that Cdk4/cyclin D1 is the main cyclin/Cdk complex responsible for the phosphorylation of $\mathrm{Rb}$ in motor neurons of mutant SOD1 mice. Further support of the Rb phosphorylation by Cdk4 is the finding of low levels of phospho-Rb in neurons of SOD $1^{\text {G37R }}$;hNF-H mice, which exhibited a deregulation of Cdk5 but not of Cdk4 at 1 year of age (see below).

\section{Minocycline, a drug that slows down disease progression, lessened dysregulation of Cdk5 and Cdk4 and Rb phosphorylation}

Minocycline, a tetracycline-derivative compound, conferred protection in mouse models of stroke, Huntington's disease, and Parkinson's disease (Yrjänheikki et al., 1999; Chen et al., 2000; Du et al., 2001; Wu et al., 2002). This protection may be related to inhibition of p38 MAP kinase in proliferating glial cells, reduction of inducible nitric oxide synthase, inhibition of cytochrome $c$ release (Zhu et al., 2002), and alleviation of caspase activation (Yrjänheikki et al., 1999; Chen et al., 2000; Du et al., 2001).

Minocycline treatment, when administered as a supplement in the rodent diet starting at the late presymptomatic stage ( 9 months old), increased the life span of SOD ${ }^{\mathrm{G} 37 \mathrm{R}}$ mice by $\sim 3$ weeks (Kriz et al., 2002). Here we further examined by immunohistochemistry whether minocycline treatment lessens the dysregulation of $\mathrm{Cdk} 5$ and $\mathrm{Cdk} 4$ in motor neurons of SOD $1{ }^{\mathrm{G} 37 \mathrm{R}}$ mice. As shown in Figure 6, there was a reduction of MAC-2 (a galactose-specific lectin) staining, a marker of activated microglia, in 10.5-month-old minocycline-treated SOD1 ${ }^{\mathrm{G} 37 \mathrm{R}}$ mice 


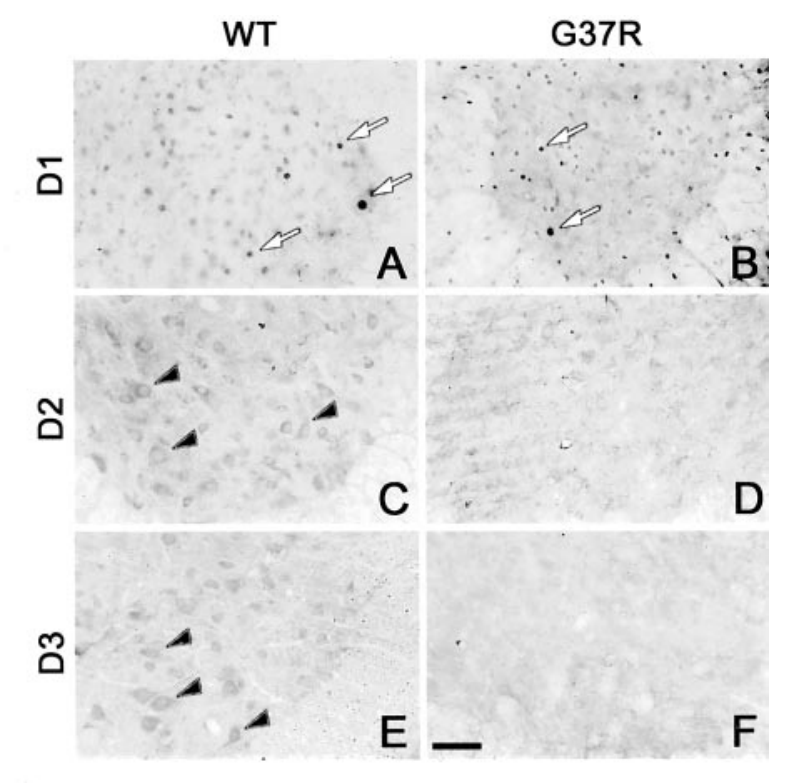

G \# axons: $1052 \pm 97(n=7) \quad 364 \pm 34(n=4)$

$\mathrm{H}$

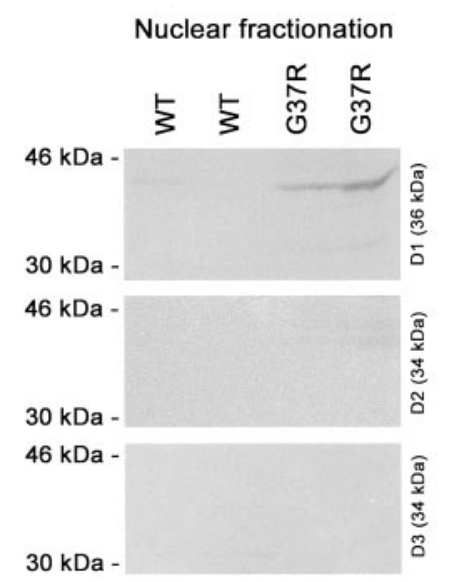

Figure 4. Increase in nuclear cyclin D1 in the spinal cord of SOD1 ${ }^{637 R}$ mice. Monoclonal antibodies against cyclin D1 yielded strong nuclear immunoreactivity in the ventral horn of the spinal cord from normal mice (WT) and SOD1 ${ }^{G 37 R}$ mice $(A, B)$, whereas antibodies against cyclins D2 and D3 stained cell bodies of spinal motor neurons $(C, E)$. The weak immunostaining for cyclins $D 2$ and $D 3$ at the end stage of disease in $S 0 D 1^{\mathrm{G} 37 \mathrm{R}}$ mice $(D, F)$ likely reflects massive neuronal loss. G, Axonal counts of $L 5$ ventral roots in WT and SOD1 ${ }^{\mathrm{G} 37 \mathrm{R}}$ mice. To determine whether an increase in Cdk4 activity is associated with increased nuclear levels of cyclin D1, we performed nuclear fractionation. Western blots show that cyclin D1 but not cyclin D2 and D3 levels increase in the nucleus of cells from mutant SOD1 but not WT mice $(H)$. Experiments were performed with spinal cord lysates and sections from four SOD1 ${ }^{\text {G37R }}$ mice (line 29) at the end stage of disease (11-12 months old) and four normal littermates and were repeated more than two times. Scale bar, $0.25 \mathrm{~mm}$.

when compared with control SOD $1^{\text {G37R }}$ littermates. Moreover, whereas intense $\mathrm{Cdk} 5$ and $\mathrm{Cdk} 4$ immunoreactivities were detected in the nucleus of spinal motor neurons in 10.5-month-old SOD $1^{\text {G37R }}$ mice (Fig. 6, B,E), weak immunostaining for Cdk5 and $\mathrm{Cdk} 4$ was detected in spinal motor neurons of minocyclinetreated SOD $1^{\text {G37R }}$ mice (Fig. 6,A,C-E). Moreover, treatment of SOD $1^{\mathrm{G} 37 \mathrm{R}}$ mice with minocycline resulted in a reduction in the phosphorylation of $\mathrm{Rb}$ (Fig. $6 \mathrm{~N}$ ). These results suggest that the dysregulation of Cdk5 and Cdk4 and $\mathrm{Rb}$ phosphorylation in SOD $1^{\mathrm{G} 37 \mathrm{R}}$ mice may occur as a neurotoxic response to stress, including inflammatory processes, at the late stage of disease.

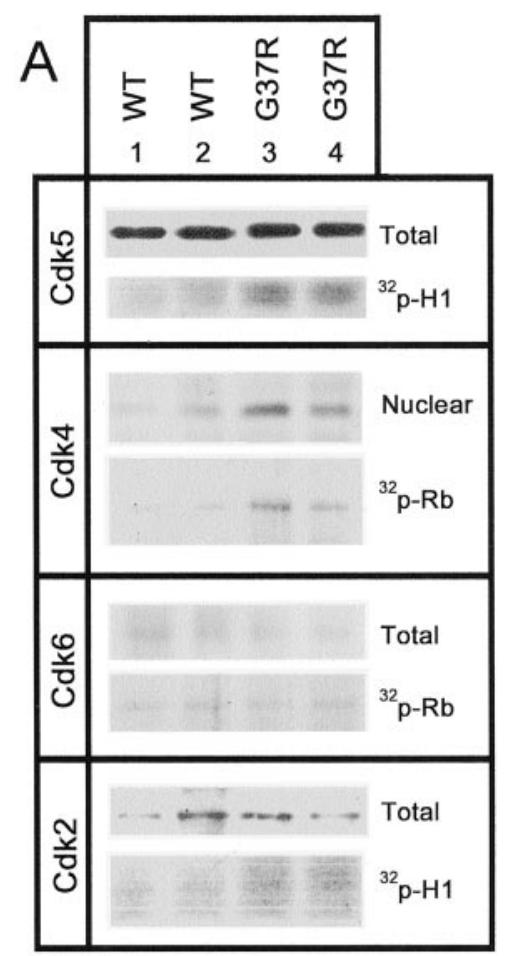

B

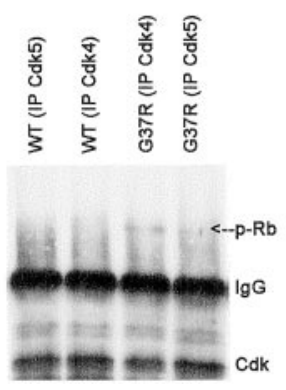

Figure 5. Upregulation of levels and kinase activity of Cdk4 associated with Rb phosphorylation in the spinal cord of SOD1 ${ }^{\text {G37R }}$ mice. $A$, Similar levels of Cdk5, Cdk6, and Cdk2 were detected by Western blotting from spinal cord extracts of normal mice (WT) and SOD1 ${ }^{\text {G37R }}$ mice. However, increased levels of C $\mathrm{dk} 4$ were detected in nuclear fractions from the spinal cord of SOD1 ${ }^{\text {G37R }}$ mice when compared with normal mice. Kinase assays were performed after immunoprecipitation of spinal cord extracts with Cdk5, Cdk4, Cdk6, and Cdk2 antibodies. The autoradiograms show the quantity of ${ }^{32} \mathrm{P}$ incorporated in histone $\mathrm{H} 1(\mathrm{Cdk5}, \mathrm{Cdk2})$ or Rb (Cdk4, $(d k 6)$ in spinal cord extracts from SOD $1^{\text {G37R }}$ mice and littermates (WT) at 11-12 months of age. The C $d k 5$ and C $d k 4$ kinase activities were increased by approximately twofold in samples from SOD $1^{\text {G37R }}$ mice, whereas no major changes in Cdk6 and Cdk2 activities were detected. B, Cdk4 but not Cdk5 can be immunoprecipitated with phospho-Rb from spinal cord lysates of SOD1 ${ }^{\text {G37R }}$ but not WT mice. The membranes were reprobed with antibodies against Cdk5, Cdk4, or phospho-Rb. IP, Immunoprecipitation. Experiments were performed with spinal cord lysates from four SOD1 ${ }^{\text {G37R }}$ mice (line 29) at the end stage of disease (11-12 months old) and four normal littermates and were repeated more than two times.

To determine whether motor neurons positive for Cdk4 exhibit signs of apoptosis, we performed double-immunohistochemical staining for Cdk4 and activated caspase- 3 on spinal cord sections from SOD $1^{\text {G37R }}$ mice. As shown in Figure $6 P$, neurons positive for both Cdk 4 and activated caspase- 3 are rarely found in those sections, yet few of them were positive for both antibodies (Fig. 6Q). This finding suggests that a deregulation of $\mathrm{Cdk} 4$ may be independent of other neuronal death pathways involving caspase-3. Another possibility, initially highlighted by Pasinelli et al. (2000) and Vukosavic et al. (2000), is that the apoptotic processes in ALS mice differ in kinetics and biochemistry from those occurring during neuronal devel- 

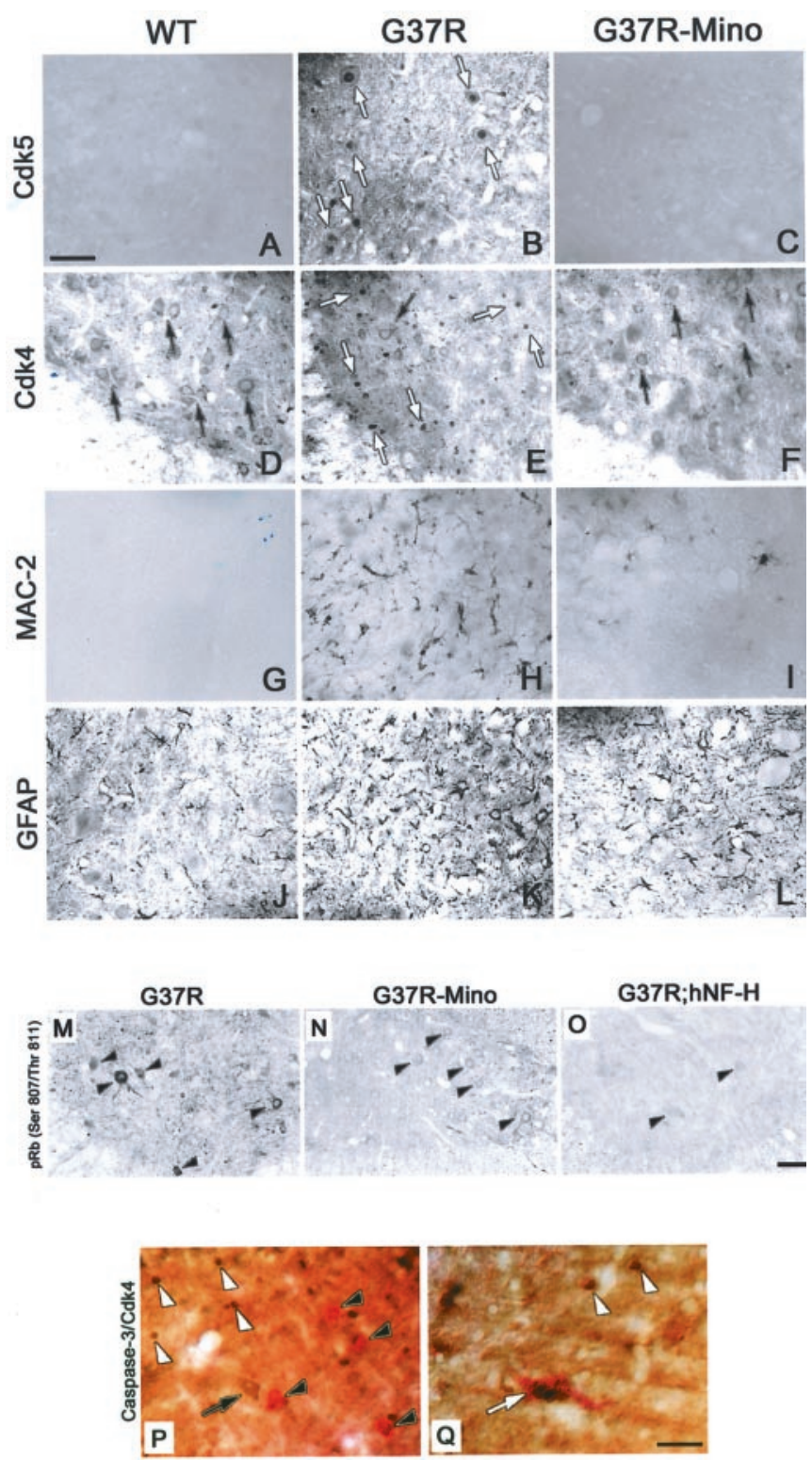

Figure 6. Attenuation of disease in SOD1 ${ }^{\text {G37R }}$ mice by minocycline treatment or by overexpression of the hNF-H transgene lessens dysregulation of $\mathrm{Cdk} 4$ and Rb phosphorylation. Antibodies against $\mathrm{Cdk} 5$ yielded strong immunoreactivities in cell bodies and nuclei of motor neurons in early presymptomatic 10.5 -month-old SOD $1{ }^{\text {G37R }}$ mice $(B)$. The same mouse also exhibited immunoreactivities for ( $\mathrm{dk} 4$ in nuclei of some motor neurons ( $E$, white arrows) as well as activation of microglia $(H)$. Microglia activation, $(\mathrm{dk} 5$ deregulation, and $\mathrm{Cdk} 4$ upregulation were reduced in motor neurons of 10.5 -month-old SOD $1{ }^{\mathrm{G} 37 \mathrm{R}}$ mice treated with minocycline at 9 months $(C, F, I)$. Similar staining intensities were found in normal littermates $(A, D, G)$. Less phosphorylation of Rb was detected in $S O D 1^{G 37 R}$ mice as a result of minocycline treatment or $\mathrm{hNF}-\mathrm{H}$ overexpression $(\mathrm{N}, \mathrm{O})$. Double immunohistochemical staining for $\mathrm{Cdk4}$ and activated caspase- 3 on spinal cord sections from SOD $1{ }^{\mathrm{G} 37 \mathrm{R}}$ mice indicates rare neurons positive for both Cdk4 and activated caspase-3 $(P)$, yet few of them were positive for both antibodies ( $Q)$. This finding suggests that a deregulation of Cdk4 may be independent of other neuronal death pathways involving caspase-3, that apoptotic processes in ALS mice differ from the one occurring during neuronal development, or both. The experiments were performed with spinal cord sections from five $\mathrm{SOD1}^{\mathrm{G} 37 \mathrm{R}}$ mice (line 29) at the end stage of disease (11-12 months old), two SOD1 ${ }^{\text {G37R }}$; hNF-H mice (12 months old), and four normal littermates. Scale bar, $50 \mu \mathrm{m}$.

opment. It is also noteworthy that none of three seminal studies on apoptosis using mutant SOD1 mice reported positive terminal deoxynucleotidyl transferase-mediated biotinylated UTP nick endlabeling staining for motor neurons, characteristic of apoptosis ( $\mathrm{Li}$ et al., 2000; Pasinelli et al., 2000; Vukosavic et al., 2000). Moreover, only

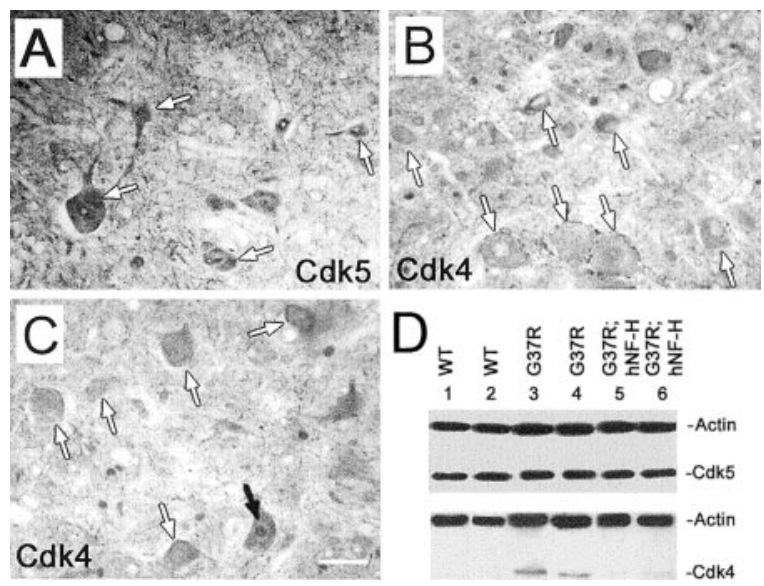

Figure 7. Overexpression of hNF-H in SOD1 ${ }^{\text {G37R }}$ mice reduces Cdk4 levels. Antibodies against $\mathrm{Cdk} 5$ yielded strong immunoreactivities for cell bodies and nuclei of motor neurons in 13-month-old SOD1 ${ }^{\text {G37R }}$ mice overexpressing hNF-H ( $A$, white arrows). However, the same mouse exhibited poor immunoreactivities for $C \mathrm{dk} 4$ in nuclei of motor neurons ( $B$, white arrows) except for one neuron ( $B$, black arrow). Similar levels of $(\mathrm{dk} 5$ were detected by Western blotting in spinal cord extracts of normal mice (WT) and SOD1 ${ }^{\text {G37R }}$ mice with or without the hNF-H transgene (lanes 1-6). In contrast, the overexpression of hNF-H decreased the total levels of Cdk4 in the spinal cord of SOD1 ${ }^{\mathrm{G} 7 \mathrm{R}}$ mice (lanes 5, 6). Actin was used as a control. Experiments were performed with spinal cord sections from three 12 - to 13 -month-old SOD1 ${ }^{637 R}$;hNF-H mice. The spinal cord samples in $D$ were prepared from three 12-month-old mice of each genotype. All experiments were repeated more than twice.

a few motor neurons in mutant SOD1 mice exhibit markers of apoptosis, although all of them express the mutant protein (Pasinelli et al., 2000; Vukosavic et al., 2000). Indeed, we and other groups demonstrated that glial cells are the main targets of apoptosis in ALS mice (Pasinelli et al., 2000; M. D. Nguyen, T. Daigle, J.-P. Julien, and S. Rivest, unpublished results). A nonapoptotic mode of neuronal cell death has been also suggested in ALS (Migheli et al., 1999). It is still controversial whether necrosis or "unusual apoptosis" is the dominant mode of neuronal cell death in ALS.

\section{Overexpression of human NF-H, a phosphorylation sink for} Cdk5, decreases the levels of nuclear Cdk4, attenuates Rb phosphorylation, and alleviates disease in SOD ${ }^{\text {G37R }}$ mice To further assess the relationship between Cdk5 and Cdk4 in neurodegeneration, we analyzed SOD $1{ }^{\mathrm{G} 37 \mathrm{R}}$ mice overexpressing the human NF-H protein (hNF-H) (Couillard-Després et al., 1998; Nguyen et al., 2001a). Our previous studies provided evidence that perikaryal neurofilament accumulations induced by overexpression of an hNF-H transgene can slow down disease in SOD $1^{\text {G37R }}$ mice by acting as a phosphorylation sink for deregulated Cdk 5 activity by p 25 , a toxic calpain-p35 truncated product (Couillard-Després et al., 1998; Patrick et al., 1999; Nguyen et al., 2001a). To further assess the effects of Cdk5 interference on Cdk4 levels, we analyzed by immunohistochemistry and Western blotting the expression of $\mathrm{Cdk} 4$ as well as phosphorylation of $\mathrm{Rb}$ in SOD $1^{\text {G37R }}$ mice overexpressing hNF-H.

As we reported before, antibodies against $\mathrm{Cdk} 5$ yielded strong immunoreactivities in the nucleus and cell bodies of spinal motor neurons from SOD1 ${ }^{\text {G37R }}$; hNF-H mice (Fig. 7A) (Nguyen et al., 2001a). In contrast, poor immunoreactivity for Cdk4 was detected in the cytoplasm and nucleus of spinal motor neurons in doubly transgenic SOD $1^{\mathrm{G} 37 \mathrm{R}} ; \mathrm{hNF}-\mathrm{H}$ mice (Fig. $7 B, C$ ). The Western blots in Figure $7 D$ further confirmed the lower levels of Cdk4 in spinal cord extracts of doubly transgenic SOD $1^{\mathrm{G} 37 \mathrm{R}}$; hNF-H mice compared with single SOD ${ }^{\text {G37R }}$ mice. Further- 
more, $\mathrm{Rb}$ phosphorylation is also greatly attenuated in doubly transgenic SOD1 ${ }^{\mathrm{G} 37 \mathrm{R}}$; $\mathrm{hNF}-\mathrm{H}$ mice compared with single SOD $1^{\mathrm{G} 37 \mathrm{R}}$ mice (Fig. 6). Thus, there was a correlation between severity of disease and a reduction of $\mathrm{Cdk} 4$ levels and $\mathrm{Rb}$ phosphorylation in both SOD ${ }^{\mathrm{G} 37 \mathrm{R}} ;$ hNF-H and minocycline-treated SOD1 ${ }^{\text {G37R }}$ mice (Nguyen et al., 2001a; Kriz et al., 2002; see above).

\section{Discussion}

The data presented here suggest that an attempted reentry of motor neurons into the $G_{1}-S$ phase of the cell cycle may be a critical step in the neuronal death pathway triggered by toxicity of mutant SOD1. Our results showed abnormal protein levels and activity of Cdk4, a regulator of the $\mathrm{G}_{1}-\mathrm{S}$ checkpoint of the cell cycle, in the nucleus of spinal motor neurons from SOD1 ${ }^{\mathrm{G} 37 \mathrm{R}}$ mice at a late stage in disease. Moreover, $\mathrm{Rb}$ was found to be abnormally phosphorylated at Ser-807 and Thr-811 in those motor neurons (Fig. 1).

There is growing evidence for involvement of cell cycle molecules in many neurodegenerative conditions. Alterations in expression and cellular distribution of cell cycle regulators have been observed in neurons of postmortem samples in Alzheimer's disease, Down's syndrome, Pick's disease, Parkinson ALS of Guam, and amyotrophic lateral sclerosis (Arendt et al., 1996; Vincent et al., 1996, 1997; McShea et al., 1997; Busser et al., 1998; Husseman et al., 2000; Ranganathan et al., 2001; Yang et al., 2001). Moreover, activation of Cdks can be triggered in brain neurons after cerebral ischemia or kainate-induced excitotoxicity as well as in cultured neurons after treatment with DNAdamaging agents, deprivation of toxic factors, or $\beta$-amyloid peptide (Park et al. 1997a,b, 1998a,b, 2000; Copani et al., 1999; Stefanis et al., 1999; Osuga et al., 2000; Ino and Chiba, 2001; Katchanov et al., 2001). Under such in vivo and in vitro conditions, neuronal death can be rescued by the use of Cdk inhibitors or dominant negative forms of the kinases (Park et al. 1997a,b, 1998a,b, 2000; Copani et al., 1999; Stefanis et al., 1999; Osuga et al., 2000; Ino and Chiba, 2001; Katchanov et al., 2001), demonstrating the central role of Cdks in the neuronal apoptotic mechanism (for review, see Nguyen et al., 2002b).

Administration of minocycline in the diet of $\mathrm{SOD}^{\mathrm{G} 37 \mathrm{R}}$ mice delayed the onset of motor neuron degeneration and slowed down disease progression (Kriz et al., 2002) presumably through the attenuation of microgliosis that produces noxious inflammatory molecules (Bruijn et al., 1997; Nguyen et al., 2001b) (for review on inflammation in neurodegeneration, see Nguyen et al., 2002a). Here, we show that the dysregulation of Cdk5 and Cdk4 at 8-9 months of age in SOD $1^{\text {G37R }}$ mice (Fig. 3) can be attenuated by minocycline, a compound that reduces inflammation during the terminal apoptotic phase of disease (Fig. 6). It is possible that the dysregulation of Cdk5 and Cdk4 may result from a neuronal toxic response to inflammatory processes. This view would be compatible with studies demonstrating a close relationship between aberrant expression of cell cycle proteins in neurons and inflammation (Jordan-Sciutto et al., 2001, 2002; Ranganathan et al., 2001).

Although abnormal activation of cell cycle Cdks and Cdk5 were detected in various neurodegenerative conditions, it has remained unclear how $\mathrm{Cdk} 5$ deregulation by $\mathrm{p} 25$ might be connected to neuronal death mediated by cell cycle Cdks. Our analysis of SOD $1{ }^{\mathrm{G} 37 \mathrm{R}}$ mice overexpressing human NF-H proteins is also consistent with a model in which Cdk5 precedes Cdk4 in the signaling pathway to neuronal death, as depicted in Figure 8. Previously, we showed that the overexpression of NF-H confers

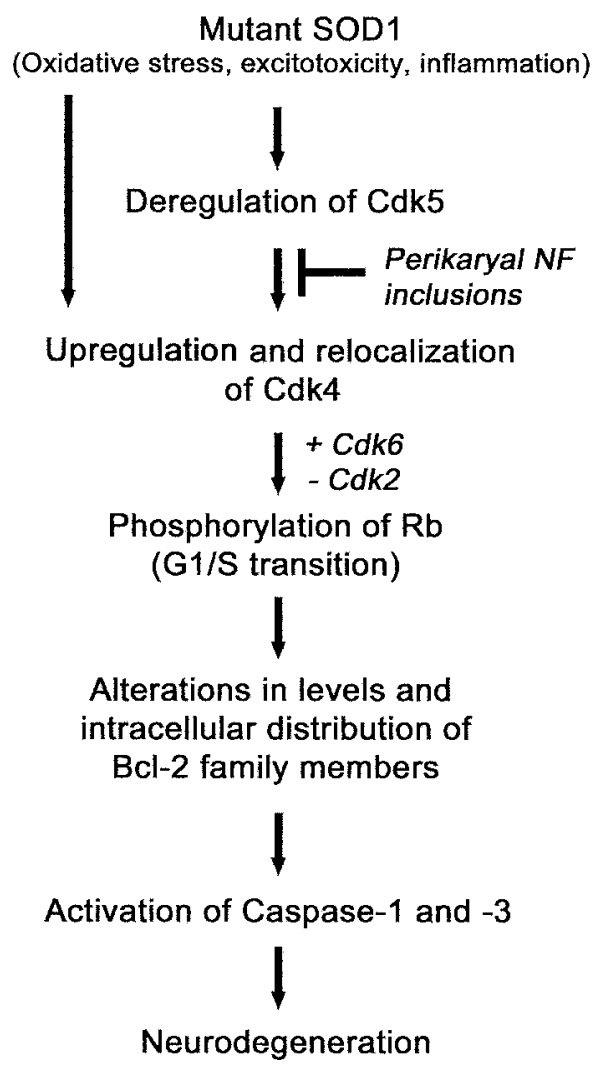

Figure 8. Model of the neuronal death pathway involving (dks. In this model, mutant SOD1, oxidative stress, excitotoxicity, and inflammation can trigger deregulation of (dk5 that subsequently upregulates $\mathrm{Cdk} 4$. The activation of nuclear $\mathrm{Cdk} 4$ leads to the phosphorylation of $\mathrm{Rb}$, promoting its dissociation from E2F-1 with ensuing transcription of proapoptotic BCl-2 family members. This provokes mitochondrial disturbances, caspase activation, and ultimately neurodegeneration. The toxicity of nuclear Cdk4 upregulation, Rb phosphorylation, and the ensuing signaling pathway can be attenuated by interference of deregulated C $\mathrm{dk} 5$ activity. For instance, this may be achieved by overexpressing NF-H, which acts as a phosphorylation sink for deregulated Cdk5 activity. Cdk4 can also be activated independently of Cdk5 deregulation.

remarkable protection and delays the mortality of SOD $1^{\mathrm{G} 37 \mathrm{R}}$ mice (Couillard-Després et al., 1998). The excess perikaryal NF-H can alleviate disease by acting as a phosphorylation sink for deregulated Cdk5 activity, thereby reducing hyperphosphorylation of other detrimental substrates such as tau (Nguyen et al., 2001a). As shown in Figure 7, unlike in single SOD $1^{\mathrm{G} 37 \mathrm{R}}$ mice, low levels of Cdk4 were detected in motor neurons of double SOD $1{ }^{\mathrm{G} 37 \mathrm{R}}$;hNF-H mice despite conversion of p35 into p 25 and deregulation of Cdk5 (Nguyen et al., 2001b). Further supporting the view that Cdk5 deregulation lies upstream of Cdk4 and $\mathrm{Rb}$ toxicity are the findings of $\mathrm{Cdk} 4$ immunoprecipitated with phospho- $\mathrm{Rb}$ and the low levels of phospho- $\mathrm{Rb}$ in neurons of SOD ${ }^{\text {G37R }}$;hNF-H mice. Thus, interfering with Cdk5 led to reduction in Cdk4 levels, $\mathrm{Rb}$ phosphorylation, and alleviation of disease severity. All these results are compatible with a model in which $\mathrm{Cdk} 5$ precedes $\mathrm{Cdk} 4$ in the degenerative signaling pathway and induction of $\mathrm{Cdk} 4$ is essential for $\mathrm{Rb}$ phosphorylation and neurodegeneration.

It is unlikely that perikaryal NF inclusions serve as a phosphorylation sink for Cdk4 activity, because in SOD $1{ }^{\mathrm{G} 37 \mathrm{R}} ; \mathrm{hNF}-\mathrm{H}$ mice, Cdk4 is almost not detectable (Fig. 7). Moreover, we were unable to precipitate Cdk4 with antibodies against phosphoNF-H (data not shown). Although we did not succeed in immunoprecipitating Cdk5 with phospho- $\mathrm{Rb}$, it remains possible that 
$\mathrm{Rb}$ is a minor target of $\mathrm{p} 25 / \mathrm{Cdk} 5$ in mutant SOD1 mice. Previously, Lee et al. (1997) demonstrated that in vitro, Rb is a substrate for p25/Cdk5. As shown in Figure 6O, a slight immunostaining for phospho- $\mathrm{Rb}$ is still detected in motor neurons of SOD $1^{\mathrm{G} 37 \mathrm{R}}$; $\mathrm{hNF}-\mathrm{H}$ mice at the stage of deregulation of Cdk5 but not Cdk4.

How might Cdk activation lead to neuronal death? It is well established that an association of cyclin D1 with Cdk4 confers to this kinase the capacity to phosphorylate $\mathrm{Rb}$ (Knudsen and Wang, 1997). In mitotic cells, phosphorylation of Rb by Cdk4 triggers initiation and progression of the cell cycle (Morgan 1997; Dyson, 1998; Tannoch et al., 2000). However, in postmitotic neurons, there is evidence that phosphorylation of $\mathrm{Rb}$ can induce apoptosis through the dissociation of $\mathrm{Rb}$ from the $\mathrm{Rb} / \mathrm{E} 2 \mathrm{~F}-1$ transcription-repressive complex and the subsequent E2F-1dependent expression of apoptotic proteins (Knudsen and Wang, 1997; Copani et al., 1999, 2001; Giovanni et al., 2000; Liu and Greene, 2001).

Studies with primary cortical neurons treated with $\beta$-amyloid peptide demonstrated that $\mathrm{Rb}$ phosphorylation by Cdk $4 / 6$ activation can be followed by the activation of the proapoptotic $\mathrm{Bcl}-2$ family member Bax, which in turn activates caspase-3, leading to apoptosis (Knudsen and Wang, 1997; Copani et al., 1999, 2001; Giovanni et al., 2000; Liu and Greene, 2001). There is evidence that alterations in levels of $\mathrm{Bax}, \mathrm{Bcl}-2$, and $\mathrm{Bcl}-\mathrm{x}$ proteins may also contribute to neurodegeneration in mutant SOD1 mice and in ALS patients (Mu et al., 1996, Ekegren et al., 1999; Martin, 1999; Vukosavic et al., 1999; Gonzalez de Aguilar et al., 2000). The overexpression of $\mathrm{Bcl}-2$ in SOD1 ${ }^{\mathrm{G} 93 \mathrm{~A}}$ mice delayed caspase- 3 activation, indicating that insults leading to an unbalanced ratio of Bcl-2 family members might promote death signals (Kostic et al., 1997; Pasinelli et al., 1998, 2000; Li et al., 2000; Vukosavic et al., 2000). Nevertheless, the apoptotic processes in mutant SOD1 mice differ by kinetics and by biochemistry from the one occurring during neuronal development (Pasinelli et al., 2000; Vukosavic et al., 2000). The classical concepts of mechanisms and timing of apoptosis may then require revision in cases of late-onset neurodegenerative disorders, evolving over months or years, such as ALS. A nonapoptotic mode of neuronal cell death has also been suggested in ALS (Migheli et al., 1999; Vukosavic et al., 2000). It is still controversial whether necrosis or unusual apoptosis is the dominant mode of neuronal cell death in ALS.

The results presented here suggest that regulators of the $G_{1}-S$ checkpoint of the cell cycle may represent key components of the signaling pathway linking the toxicity of mutant SOD1 to an unusual neuronal death pathway initiated by Bcl-2 family members and caspase activation (Fig. 8). Accordingly, inhibitors of Cdks, already known to be protective in different neurodegenerative conditions, might provide potential therapeutic avenues for ALS treatment.

\section{References}

Abi-Farah CA, Nguyen MD, Julien JP, Leclerc N (2002) Alterations in microtubule associated proteins before disease onset in a mouse model of amyotrophic lateral sclerosis. J Neurochem 84:77-86.

Arendt T, Rodel L, Gartner U, Holzer M (1996) Expression of the cyclindependent kinase inhibitor p16 in Alzheimer's disease. NeuroReport 7:3047-3049.

Bruijn LI, Becher MW, Lee MK, Anderson KL, Jenkins NA, Copeland NG, Sisodia SS, Rothstein JD, Borchelt DR, Price DL, Cleveland DW (1997) ALS-linked SOD1 mutant G85R mediates damage to astrocytes and promotes rapidly progressive disease with SOD1-containing inclusions. Neuron 18:327-338.

Bruijn LI, Houseweart MK, Kato S, Anderson KL, Anderson SD, Ohama E, Rheaume AG, Scott RW, Cleveland DW (1998) Aggregation and motor neuron toxicity of an ALS-linked SOD1 mutant independent from wildtype SOD1. Science 281:1851-1854.

Busser J, Geldmacher DS, Herrup K (1998) Ectopic cell cycle proteins predict the sites of neuronal cell death in Alzheimer's disease brain. J Neurosci 18:2801-2807.

Chen M, Ona VO, Li M, Ferrante RJ, Fink KB, Zhu S, Bian J, Guo L, Farrellm LA, Hersch SM, Hobbs W, Vonsattel JP, Cha JH, Friedlander RM (2000) Minocycline inhibits caspase- 1 and caspase- 3 expression and delays mortality in a transgenic mouse model of Huntington disease. Nat Med 6:797-801.

Cleveland DW, Rothstein JD (2001) From Charcot to Lou Gehrig: deciphering selective motor neuron death in ALS. Nat Rev Neurosci 2:806-819.

Copani A, Condorelli F, Caruso A, Vancheri C, Sala A, Giuffrida Stella AM, Canonico PL, Nicoletti F, Sortino MA (1999) Mitotic signaling by betaamyloid causes neuronal death. FASEB J 13:2225-2234.

Copani A, Uberti D, Sortino MA, Bruno V, Nicoletti F, Memo M (2001) Activation of cell-cycle-associated proteins in neuronal death: a mandatory or dispensable path? Trends. Neurosci 24:25-31.

Couillard-Després JS, Zhu Q, Wong PC, Price DL, Cleveland DW, Julien JP (1998) Protective effect of neurofilament heavy gene overexpression in motor neuron disease induced by mutant superoxide dismutase. Proc Natl Acad Sci USA 95:9626-9630.

Cudkowicz ME, McKenna-Yasek D, Sapp PE, Chin W, Geller B, Hayden DL, Schoenfeld DA, Hosler BA, Horvitz HR, Brown RH (1997) Epidemiology of mutations in superoxide dismutase in amyotrophic lateral sclerosis. Ann Neurol 41:210-221.

Dhavan R, Tsai LH (2001) A decade of CDK5. Nat Rev Mol Cell Biol 2:749-759.

Du Y, Ma Z, Lin S, Dodel RC, Gao F, Bales KR, Triarhou LC, Chernet E, Perry KW, Nelson DL, Luecke S, Phebus LA, Bymaster FP, Paul SM (2001) Minocycline prevents nigrostriatal dopaminergic neurodegeneration in the MPTP model of Parkinson's disease. Proc Natl Acad Sci USA 98:14669-14674.

Dyson N (1998) The regulation of E2F by pRB-family proteins. Genes Dev 12:2245-2262.

Ekegren T, Grundstrom E, Lindholm D, Aquilonius SM (1999) Upregulation of Bax protein and increased DNA degradation in ALS spinal cord motor neurons. Acta Neurol Scand 100:317-321.

Fridovich I (1986) Superoxide dismutases. Adv Enzymol Relat Areas Mol Biol 58:61-97.

Giovanni A, Keramaris E, Morris EJ, Hou ST, O’Hare M, Dyson N, Robertson GS, Slack RS, Park DS (2000) E2F1 mediates death of B-amyloid-treated cortical neurons in a manner independent of $\mathrm{p} 53$ and dependent on Bax and caspase 3. J Biol Chem 275:11553-11560.

Gonzalez de Aguilar JL, Gordon JW, Rene F, de Tapia M, Lutz-Bucher B, Gaiddon C, Loeffler JP (2000) Alteration of the Bcl-x/Bax ratio in a transgenic mouse model of amyotrophic lateral sclerosis: evidence for the implication of the p53 signaling pathway. Neurobiol Dis 7:406-415.

Gurney ME, Pu H, Chiu AY, Dal Canto MC, Polchow CY, Alexander DD, Caliendo J, Hentati A, Kwon YW, Deng HX, Chen W, Zhai P, Sufit RL, Siddique T (1994) Motor neuron degeneration in mice that express a human $\mathrm{Cu}, \mathrm{Zn}$ superoxide dismutase mutation. Science 264:1772-1775.

Husseman JW, Nochlin D, Vincent I (2000) Mitotic activation: a convergent mechanism for a cohort of neurodegenerative diseases. Neurobiol Aging 21:815-828.

Ino $\mathrm{H}$, Chiba $\mathrm{T}$ (2001) Cyclin-dependent kinase 4 and cyclin D1 are required for excitotoxin-induced neuronal cell death in vivo. J Neurosci 21:6086-6094.

Julien JP (2001) Amyotrophic lateral sclerosis: unfolding the toxicity of the misfolded. Cell 104:181-191.

Jordan-Sciutto K, Wang G, Murphey-Corb M, Wiley CA (2001) Induction of cell cycle regulators in simian immunodeficiency virus encephalitis. Am J Pathol 157:497-507.

Jordan-Sciutto KL, Wang G, Murphey-Corb M, Wiley CA (2002) Cell cycle proteins exhibit altered expression patterns in lentiviral-associated encephalitis. J Neurosci 22:2185-2195.

Katchanov J, Harms C, Gertz K, Hauck L, Waeber C, Hirt L, Priller J, von Harsdorf R, Bruck W, Hortnagl H, Dirnagl U, Bhide PG, Endres M (2001) Mild cerebral ischemia induces loss of cyclin-dependent kinase inhibitors and activation of cell cycle machinery before delayed neuronal cell death. J Neurosci 21:5045-5053. 
Kikuchi H, Doh-ura K, Kawashima T, Kira J, Iwaki T (1999) Immunohistochemical of spinal cord lesions in amyotrophic lateral sclerosis using microtubule-associated protein 2 (MAP2) antibodies. Acta Neuropathol (Berl) 97:13-21.

Knudsen ES, Wang JYJ (1997) Dual mechanisms for the inhibition of E2F binding to RB by cyclin-dependent kinase-mediated RB phosphorylation. Mol Cell Biol 17:5771-5783.

Kostic V, Jackson-Lewis V, De Bilbao F, Dubois-Dauphin M, Przedborski S (1997) Bcl-2: prolonging life in a transgenic mouse model of familial amyotrophic lateral sclerosis. Science 227:559-562.

Kriz J, Nguyen MD, Julien JP (2002) Minocycline slows down disease progression in a mouse model of amyotrophic lateral sclerosis. Neurobiol Dis $10: 268-278$.

Lee KY, Helbing CC, Choi KS, Johnston RN, Wang JH (1997) Neuronal Cdc2-like kinase $(\mathrm{Nclk})$ binds and phosphorylates the retinoblastoma protein. J Biol Chem 272:5622-5626.

Lee MS, Kwon YT, Li M, Peng J, Friedlander RM, Tsai LH (2000) Neurotoxicity induces cleavage of p35 to p25 by calpain. Nature 405:360-364.

Li M, Ona VO, Guégan C, Chen M, Jackson-Lewis V, Andrews LJ, Olzewski AJ, Stieg PE, Lee JP, Przedborski S, Friedlander RM (2000) Functional role and therapeutic implications of neuronal caspase- 1 and -3 in a mouse model of traumatic spinal cord injury. Science 288:335-339.

Lipinski M, Jacks T (1999) The retinoblastoma gene family in differentiation and development. Oncogene 18:7873-7882.

Liu DX, Greene LA (2001) Neuronal apoptosis at the G1/S cell cycle checkpoint. Cell Tissue Res 305:217-228.

Martin LJ (1999) Neuronal death in amyotrophic lateral sclerosis is apoptosis: possible contribution of a programmed cell death mechanism. J Neuropathol Exp Neurol 58:459-471.

McShea A, Harris PL, Webster KR, Wahl AF, Smith MA (1997) Abnormal expression of the cell cycle regulators P16 and CDK4 in Alzheimer's disease. Am J Pathol 150:1933-1939.

Migheli A, Atzori C, Piva R, Tortarolo M, Girelli M, Schiffer D, Bendotti C (1999) Lack of apoptosis in mice with ALS. Nat Med 9:966-967.

Morgan DO (1997) Cyclin-dependent kinases: engines, clocks, and microprocessors. Annu Rev Cell Dev Biol 13:261-291.

Morrison BM, Janssen WG, Gordon JW, Morrison JH (1998) Time course of neuropathology in the spinal cord of G86R superoxide dismutase transgenic mice. J Comp Neurol 391:64-77.

Mu X, He J, Anderson DW, Trojanowski JQ, Springer JE (1996) Altered expression of bcl-2 and bax mRNA in amyotrophic lateral sclerosis spinal cord motor neurons. Ann Neurol 40:379-386.

Nguyen MD, Larivière RC, Julien JP (2000) Reduction of axonal caliber does not alleviate motor neuron disease caused by mutant superoxide dismutase 1. Proc Natl Acad Sci USA 97:12306-12311.

Nguyen MD, Larivière RC, Julien JP (2001a) Deregulation of Cdk5 in a mouse model of ALS: toxicity alleviated by perikaryal neurofilament inclusions. Neuron 30:135-147.

Nguyen MD, Julien JP, Rivest S (2001b) Induction of pro-inflammatory molecules in mice with amyotrophic lateral sclerosis: no requirement for pro-apoptotic Interleukin-1b in neurodegeneration. Ann Neurol 50:630-639.

Nguyen MD, Julien JP, Rivest S (2002a) Innate immunity: the missing link in neuroprotection and neurodegeneration? Nat Rev Neurosci 3:216-227.

Nguyen MD, Mushynski WE, Julien JP (2002b) Cycling at the interface between neurodevelopment and neurodegeneration. Cell Death Differ 9:1294-1306.

Osuga H, Osuga S, Wang F, Fetni R, Hogan MJ, Slack RS, Hakim AM, Ikeda JE, Park DS (2000) Cyclin-dependent kinases as a therapeutic target for stroke. Proc Natl Acad Sci USA 18:10254-10259.

Park DS, Morris EJ, Greene LA, Geller HM (1997a) G1/S cell cycle blockers and inhibitors of cyclin-dependent kinases suppress camptothecininduced neuronal apoptosis. J Neurosci 17:1256-1270.

Park DS, Levine B, Ferrari G, Greene LA (1997b) Cyclin dependent kinase inhibitors and dominant negative cyclin dependent kinase 4 and 6 promote survival of NGF-deprived sympathetic neurons. J Neurosci 17:8975-8984.

Park DS, Morris EJ, Padmanabhan J, Shelanski ML, Geller HM, Greene LA (1998a) Cyclin-dependent kinases participate in death of neurons evoked by DNA-damaging agents. J Cell Biol 143:457-467.

Park DS, Morris EJ, Stefanis L, Troy CM, Shelanski ML, Geller HM, Greene LA (1998b) Multiple pathways of neuronal death induced by DNA- damaging agents, NGF deprivation, and oxidative stress. J Neurosci 18:830-840.

Park DS, Obeidat A, Giovanni A, Greene LA (2000) Cell cycle regulators in neuronal death evoked by excitotoxic stress: implications for neurodegeneration and its treatment. Neurobiol Aging 21:771-781.

Pasinelli P, Borchelt DR, Houseweart MK, Cleveland DW, Brown RH (1998) Caspase- 1 is activated in neural cells and tissue with amyotrophic lateral sclerosis-associated mutations in copper-zinc superoxide dismutase. Proc Natl Acad Sci USA 95:15763-15768.

Pasinelli P, Houseweart MK, Brown RH, Cleveland DW (2000) Caspase-1 and -3 are sequentially activated in motor neuron death in $\mathrm{Cu}, \mathrm{Zn}$ superoxide dismutase-mediated familial amyotrophic lateral sclerosis. Proc Natl Acad Sci USA 97:13901-13906.

Patrick GN, Zukerberg L, Nikolic M, de la Monte S, Dikkes P, Tsai LH (1999) Conversion of p35 to p 25 deregulates Cdk5 activity and promotes neurodegeneration. Nature 402:615-622.

Ranganathan S, Scudiere S, Bowser R (2001) Hyperphosphorylation of the retinoblastoma gene product and altered subcellular distribution of E2F1 in Alzheimer's disease and amyotrophic lateral sclerosis. J Alzheimer's Dis 3:377-385.

Rosen DR, Siddique T, Patterson D, Figlewicz DA, Sapp P, Hentati A, Donaldson D, Goto J, O’Regan JP, Deng HX, Rachmani Z, Krizus A, McKenna-Yasek D, Cayabyab A, Gaston SM, Berger R, Tanzi RE, Halperin JJ, Herzfeldt B, Bergh RVD, et al. (1993) Mutations in Cu/Zn superoxide dismutase gene are associated with familial amyotrophic lateral sclerosis. Nature 362:59-62.

Smith DS, Greer PL, Tsai LH (2001) Cdk5 on the brain. Cell Growth Differ 12:277-283.

Stefanis L, Park DS, Friedman WJ, Greene LA (1999) Caspase-dependent and -independent death of camptothecin-treated embryonic cortical neurons. J Neurosci 19:6235-6247.

Tannoch VJ, Hinds PW, Tsai LH (2000) Cell cycle control. Adv Exp Med Biol 465:127-140.

Tu PH, Raju P, Robinson KA, Gurney ME, Trojanowski JQ, Lee VMY (1996) Transgenic mice carrying a human mutant superoxide dismutase transgene develop neuronal cytoskeletal pathology resembling human amyotrophic lateral sclerosis lesions. Proc Natl Acad Sci USA 93:3155-3160.

Vincent I, Rosado M, Davies P (1996) Mitotic mechanisms in Alzheimer's disease? J Cell Biol 132:413-425.

Vincent I, Jicha G, Rosado M, Dickson DW (1997) Aberrant expression of mitotic cdc2/cyclin B1 kinase in degenerating neurons of Alzheimer's disease brain. J Neurosci 17:3588-3598.

Vukosavic S, Dubois-Dauphin M, Romero N, Przedborski S (1999) Bax and Bcl-2 interaction in a transgenic mouse model of familial amyotrophic lateral sclerosis. J Neurochem 73:2460-2468.

Vukosavic S, Stefanis S, Jackson-Lewis V, Guégan C, Romero N, Chen C, Dubois-Dauphin M, Przedborski S (2000) Delaying caspase activation by $\mathrm{Bcl}-2$ : a clue to disease retardation in a transgenic mouse model of amyotrophic lateral sclerosis. J Neurosci 20:9119-9125.

Williamson TL, Cleveland DW (1999) Slowing of axonal transport is a very early event in the toxicity of ALS-linked SOD1 mutants to motor neurons. Nat Neurosci 2:50-56.

Wong PC, Pardo CA, Borchelt DR, Lee MK, Copeland NG, Jenkins NA, Sisodia SS, Cleveland DW, Price DL (1995) An adverse property of a familial ALSlinked SOD1 mutation causes motor neuron disease characterized by vacuolar degeneration of mitochondria. Neuron 14:1105-1116.

Wu DC, Jackson-Lewis V, Vila M, Tieu K, Teismann P, Vadseth C, Choi DK, Ischiropoulos H, Przedborski S (2002) Blockade of microglial activation is neuroprotective in the 1-methyl-4-phenyl-1,2,3,6-tetrahydropyridine mouse model of Parkinson's disease. J Neurosci 22:1763-1771.

Yang Y, Geldmacher DS, Herrup K (2001) DNA replication precedes neuronal cell death in Alzheimer's disease. J Neurosci 21:2661-2668.

Yrjänheikki J, Tikka T, Keinänen R, Goldsteins G, Chan PH, Koistinaho J (1999) A tetracycline derivative, minocycline, reduces inflammation and protects against focal cerebral ischemia with a wide therapeutic window. Proc Natl Acad Sci USA 96:13496-13500.

Zhu S, Stavrovskaya IG, Drozda M, Kim BY, Ona V, Li M, Sarang S, Liu AS Hartley DM, du Wu C, Gullans S, Ferrante RJ, Przedborski S, Kristal BS, Friedlander RM (2002) Minocycline inhibits cytochrome $c$ release and delays progression of amyotrophic lateral sclerosis in mice. Nature 417: $74-78$. 